\title{
PROCESSO DE "INVISIBILIDADE" DOS ÍNDIOS KARIRI NOS SERTÕES DOS CARIRIS NOVOS NA SEGUNDA METADE DO SÉCULO XIX
}

\author{
Antonio José de Oliveira*
}

\begin{abstract}
RESUMO: Pretendemos expor aqui as discussões sobre o processo de "invisibilidade" dos índios Kariri que habitaram os sertões dos Cariris Novos, região Sul da Província do Ceará, na segunda metade do século XIX. Ali, a historiografia local defendia que esses nativos tinham sido quase todos dizimados nas guerras contra os colonos no período colonial, especialmente no século XVIII, e os que sobreviveram a estes conflitos foram agrupados nos aldeamentos construídos naquela localidade. Dali, ainda no século XVIII, foram descidos para as aldeias do litoral da Província. Com tais acontecimentos, no século seguinte, especialmente a partir da sua segunda metade, se acreditou que esses nativos tinham sido totalmente extintos do Sul da Província. Discurso que perdurou na sociedade não índia e na produção historiográfica local por quase todo o século XX.
\end{abstract}

PALAVRAS-CHAVE: Extermínio; Sertões; Etnia Kariri.

\section{The Kariri indians “invisibility" process in Cariris Novos hinterlands on thesecond half of $19^{\text {th }}$ Century}

\begin{abstract}
Here, we intend to expose discussions about the speeches of the "invisibility" process of the Kariri Indians who inhabited the hinterlands of New Cariris, Southern province region from Ceará, in second half $19^{\text {th }}$ Centuty. There, the local historiography maintained that the natives had been almost wiped out in the war against the settlers during the colonial period, especially in the XVIII century, and those who survived had to undergo in the settlements built in that locality. Thereafter, also in the XVIII century, they were diverted to the villages situated on the coast of the province. With such events, the next century, especially on the second half, it was believed that soon these natives would have ceased to exist in Southern province. This speech remained among the non-indian groups as well as in the local historiography for the whole $20^{\text {th }}$ Century long.
\end{abstract}

KEYWORDS: Extermination; Hinterlands; Kariri ethnicities.

\section{Proceso de "invisibilidad" de los indios Kariri en interior del Cariris Novos en la segunda mitad del siglo XIX}

RESUMEN: Pretendemos realizar discusiones relativas a los discursos del proceso de "invisibilidad" de los indios Kariri que entonces habitaban los rincones de los Cariris Nuevos, en el Sur de la Provincia de Ceará, en la segunda mitad del siglo XIX. La historiografía local defendía la idea de que los nativos habían sido casi todos exterminados en las guerras en contra los colonos en el periodo colonial, en especial durante el siglo XVIII. Los sobrevivientes quedaron bajo control de las aldeas construidas en aquella localidad. Desde allí, aun mientras se desarrollaba el siglo XVIII, fueron llevados a las aldeas ubicadas en la costa de la Provincia. Por ello, en la segunda mitad del siglo siguiente, se acreditaba que poco a poco los nativos desaparecerían del Sur de la Provincia.

PALABRAS CLAVE: Exterminio; Sertões; Etnias Kariris.

\footnotetext{
* Doutorando do Programa de Pós-graduação em História Social da Universidade Federal do Ceará. Prof. do Departamento de História da Universidade Regional do Cariri. Email: luberlarmino@ig.com.br
} 


\section{Introdução}

O Sul do Estado do Ceará, comumente denominado de Região do Cariri ${ }^{1}$ com pouco mais de $4.000 \mathrm{~km}^{2}$ e congregando mais de trinta cidades, foi no período colonial e provincial denominado de "Sertões dos Cariris Novos" ou simplesmente "Cariris Novos". Na época colonial (1700-1800) compreendia quase todo o território Sul da Capitania, no que corresponde hoje as cidades de Crato, Missão Velha, Barbalha, Barra do Jardim (atual Jardim), São Pedro (atual Caririaçu), Santanópolis (atual Santana do Cariri), Brejo da Barbosa (atual Brejo Santo), Milagres e Porteiras.

A denominação "Sertões dos Cariris Novos", se processou durante conquista e colonização para diferenciar de outro território situado na Capitania da Paraíba cognominado também de "Sertões dos Cariris. " Como foi conquistado e colonizado muito antes dos territórios Sul da Capitania do Ceará, foi designado de "Sertões dos Cariris Velhos". Os elementos relevantes para essa diferenciação são as disparidades climáticas e paisagísticas existentes entre essas duas áreas. A Região dos "Cariris Velhos" está localizada numa zona com baixa pluviosidade e com paisagem essencialmente dominada pela Caatinga, enquanto que os "Cariris Novos", ao contrário, se situa em uma área em que o volume de chuvas é bem mais expressivo e predomina uma considerável área florestal.

Contudo, o que havia de comum entre essas duas localidades no período de suas respetivas conquistas consistia nos índios Kariri que nelas habitavam e cujos territórios ainda hoje ostentam o nome desses nativos. Muito embora na atualidade o topônimo "Cariri”, cite aqui o Sul do Estado do Ceará, remeta a esses nativos, a Memória e a História desses índios, ainda não são alvo de estudos por parte de muitos estudiosos da região.

Grande parte desse desprendimento, está intimamente relacionada às concepções da "não" inexistência dos Kariri contidas nas produções historiográficas sobre aquela região durante seu processo de colonização. Por todo século XX, esses materiais reproduziram quase que os mesmos entendimentos contemplados nos estudos realizados pelos intelectuais do restante da Província do Ceará, especialmente os vinculados ao Instituto Histórico, ou seja, a crença no total desaparecimento dos índios.

Só a partir dos anos noventa é que se passa a produzir com maior envergadura estudos inovadores sobre a história dos índios no Ceará. Nessa "nova" retomada, destaque para Maria Sylvia Porto Alegre, que em suas produções foi pioneira em problematizar e desconstruir a 
ideia de que os índios do Ceará haviam desaparecido. No artigo, Aldeias indígenas $e$ povoamento do Nordeste no final do século XVIII: Aspectos demográficos da "cultura de contato", a autora demonstra quantitativa e qualitativamente a situação populacional das capitanias anexas a de Pernambuco. Ao fazer um levantamento nas aldeias de índios na Capitania do Ceará, identificou que as mais populosas eram as de Viçosa (4.900 habitantes) e Crato $(2.792)^{2}$.

Tendo por base a quantificação dos índios existentes nas demais aldeias e contrapondo-se ao discurso dos estudiosos do século XIX de que os nativos haviam desaparecido do território da Província, a referida estudiosa passou a contestar essa afirmação. Percebe-se isto no artigo Cultura e história: sobre o desaparecimento dos povos indígenas ${ }^{3}$. Neste trabalho se percebe o rigor teórico-metodológico e o alcance de suas análises pelo criterioso estudo da miscelânea de fontes que utilizou.

Essas novas abordagens foram frutos da aproximação entre Antropólogos e Historiadores, que passaram a proporcionar melhores entendimentos sobre história indígena e do indigenismo não só do Ceará, mas do Brasil como um todo. Entre os reesponsáveis por essa nova e pujante produção nacional, podem-se destacar Jonh Manuel Monteiro ${ }^{4}$, Manuela Carneiro da Cunha ${ }^{5}$, Pedro Puntoni ${ }^{6}$, que em seus respectivos trabalhos buscaram compreender a dinâmica da sociedade nativa e consequentemente liberando-a das "amarras" em que ficou "presa" no contexto do século XIX e boa parte do XX.

\section{A “invisibilidade" dos Kariri no século XIX}

A partir da segunda metade do século XIX, o estudo sobre a História do Brasil ganhou uma organização teórico-metodológica mais consistente. Uma das razões para isto, foram os debates sobre a formação do Estado-Nação, os quais vinham desde a independência num processo de amadurecimento político institucional - onde se buscava definir uma identidade para o dito Estado que passaria a ganhar força e intensidade com o Instituto Histórico Geográfico Brasileiro, criado em 1838. Ali, será o lócus privilegiado da institucionalização e reflexão da pesquisa histórica na busca dessa tal identidade ${ }^{7}$. A produção dos intelectuais daquela instituição, buscou traçar o perfil dos grupos sociais que deveriam fazer parte da Nação recém-independente. Naquele contexto

O novo projeto consistia em unir as diferentes classes sob uma mesma identidade social, ou seja, todos os indivíduos que estivessem inseridos no espaço geopolítico de uma nação teriam que se reconhecerem como pertencentes da mesma. Para tanto, 
houve o trabalho de construção de uma memória e história com o objetivo de criar um sentimento de propriedade e pertencimento cultural na população ${ }^{8}$.

Nesse sentido, os países que se propuseram a projetar esse novo horizonte sociocultural, lançaram mão de vários mecanismos e critérios para compor e construir a memória e a história de seu povo. No império brasileiro, por todo o século XIX, foi incentivada a realização de viagens filosóficas e mais tarde Expedições Científicas, as quais tinham como principal incumbência descrever a história natural e em menor escala a população. Nesse caso,

No Brasil, as expedições científicas e as conseqüentes narrativas de viagem tornamse numerosas a partir do século XIX, após o processo de abertura econômica e política, ocorrido com a chegada da família real portuguesa, no ano de 1808 . O número de viajantes aumenta vertiginosamente, sendo que os objetivos dos naturalistas foram os mais variados possíveis $(. . .)^{9}$

Para as Províncias do Norte, sobretudo a do Ceará, as viagens filosóficas foram iniciadas ainda nos finais do século XVIII. Ali, quem primeiro principiou foi João da Silva Feijó, que realizou estudos sobre a história natural, bem como a "organização da exploração de salitre em diversas regiões" ${ }^{\prime 10}$. Mediante suas atividades, foram se desenhando os princípios das explorações científicas na Capitania, que passou a se consolidar a partir da segunda metade do século XIX, com a instituição da primeira Comissão Científica, que teve uma logística de execução mais eficiente.

Conhecida como Comissão do Ceará, e ainda "Comissão das Borboletas", foi presidida por Francisco Freire Alemão e Cisneiros (1797-1874). Atuando por mais de dois anos (1859-1861) os integrantes da referida Comissão, exploraram, além do Ceará, as Províncias da Paraíba, Rio Grande do Norte, Pernambuco e Piauí ${ }^{11}$. Quando percorreu os sertões da Província do Ceará, especialmente em direção aos do Sul, onde chegou em 1860, a Comissão, além das descrições sobre da fauna e a flora, dedicou também atenção à população. Freire Alemão observou que

A gente toda que tenho visto, os homens são, ou foram vaqueiros; quase todos trazem o chapéu e gibão de coiro, outros em vestimenta completa. São afáveis, obsequiosos, francos, e me pareceu de boa índole(...) os meninos são bonitos, e espertos. Quase todos têm cor morena, e vermelha, bons dentes, bonitos olhos; alguns são claros, loiros. As mulheres aparecem pouco(... $)^{12}$

Quando chegou na cidade de Icó, relatou que "há mais escravos que indígenas; assim o povo é composto de brancos, pretos mulatos - cabras - e poucos indígenas e mamelucos"13. Naquelas ribeiras, foi onde se concentrou o maior número de índios, como também primeiro núcleo urbano de expressão construído no século XVIII. Os poucos indígenas de que fala 
Freire Alemão eram os que ainda resistiam à usurpação de seus territórios nos séculos anteriores.

Chama a atenção não se ter descrições mais detalhadas desses nativos. Tal silêncio está vinculado a incompreensão da sociedade não índia do valor e contribuição que os índios poderiam oferecer àquela nova proposta de Estado-nação. Daí ser muito pequena e quase imperceptível a presença aborígine naqueles relatos como também em outros documentos oficiais, especialmente Censos. No único Censo realizado pelo Império em toda as suas Províncias, na do Ceará os índios foram incluídos junto a categoria social cabocla. Essa categoria, escondeu milhares de nativos dos registros oficiais do Império e depois da República Federativa do Brasil por quase todo o século XX.

Nas ribeiras do Salgado, sertão dos Cariris Novos, os índios que ali ainda habitavam, na sua maioria da nação ${ }^{14}$ Kariri, quase não figuram nos relatórios dos integrantes da Comissão. Ali, especialmente no Crato, sua mais expressiva vila, menos de trinta anos antes, o botânico inglês, George Gardner documentou que a maioria da população era de índios. $\mathrm{O}$ referido estudioso, encontrou e documentou também grupos étnicos ${ }^{15}$ que integravam a nação Kariri na Vila de Jardim, limites com a de Crato. Com isto, não se pode imaginar que em menos de trinta anos já estivessem todos miscigenados, tornando imperceptíveis as observações dos integrantes da Comissão. O pouco que se tem descrito é sobre uma etnia que, segundo os observadores, ainda habitavam terras na Vila de Milagres. Vejamos:

Ontem a noite em casa do Sr. Franklin de Lima, caindo a conversa sobre índios, disse o Sr, Franklin que o resto de tribo (cujo nome não se sabe) que hoje reduzida a uns 50 ou 60 existe ali por Milagres, pertenceu a uma nação que habitava por Piancó, Brejo Verde e Pajeu de Flores, onde ainda em 1816 existia inteira; e foi nessa ocasião aldeada pelo Padre Frei Ângelo, que ali fez uma grande casa quadrada com pátio dentro, onde êle os doutrinava; morreu o missionário, cessou esse ensino ${ }^{16}$.

Os índios de que o Sr. Franklin fala eram os Xocó. Estes nativos foram aldeados pelo capuchinho italiano Frei Vital de Frescarolo nas aldeias de Gameleira e Jacaré na vertente oriental da Serra do Araripe, no início do século XIX. O Padre Frei de que fala o Sr. Franklin, era Frei Ângelo Mauricio de Niza. Este, em 1803, substituiu ao Frei Vital de Frescarolo nos referidos Aldeamentos ${ }^{17}$. Ainda sobre essa etnia, quem narra é a cunhada do Sr. Franklin. Ela observa que,

Os índios vinham muito a sua caza e pediam para o festejar com suas danças. Cantos e musica, e diz a Senhora que não deixava de ser coisa engraçada. Andavam todos nus, trazendo apenas uma tanga; lançavam de si uma catinga insuportável, catinga d' arara, diz ela.(...)quando em caza fazia matulagem (se matava rês) as índias se vinham por em roda esperando ansiosas que lhes desse um pedacinho, e quando recebiam iam as duazinhas muito satisfeitas conversando em sua língua, para a 
cozinha, lançavam a carne sobre as brasas apenas sapecadas, e sem sal a devoravam sôfregas. Comiam toda qualidade de bichos; era para elas quando apanhavam um calangro (lagartinho) uma festa; lançava-no no fogo inteiro com tripas, e o devoravam. Etc ${ }^{18}$.

A dança, o canto, o odor, a forma e de que se alimentavam causava repulsa aos nãoíndios. Estes e outros costumes, na compreensão dos adventícios, significava o sinal da bestialidade daquela etnia. Ao ouvir tal narrativa, os integrantes da Comissão ficavam a resolver se apontavam e buscavam mecanismos para "domesticá-los" a se tornarem aptos ao convívio da sociedade dita civilizada ou simplesmente ignorar sua existência.

Dotados do dito conhecimento científico, os componentes da Expedição tinham o "poder" de definir até que ponto os nativos poderiam contribuir para o progresso daquela sociedade. Em vista disto, "o discurso sobre o novo prendeu-se à degeneração, à minoridade, à barbárie, enfim, ao entendimento de um universo cultural ontologicamente pútrido, incapaz de algum tipo de progresso sem a intervenção do homem civilizado europeu."19 Nesse sentido, a Comissão passou a ser ponto de referência para que não só o Estado, mas os intelectuais da época pudessem também compreender e delimitar em suas produções a preferência barbárie/civilização, bem como, poder contribuir e atribuir opiniões sobre as categorias sociais que poderiam tomar parte daquele corpo social e serem outorgados como legítimos cidadãos.

As expedições inspiram muitas análises sobre o Brasil, especialmente em relação ao lugar da população nativa. Dentre as principais produções daquela época, se destaca, História Geral do Brasil, de Francisco de Adolfo de Varnhagen. Na sua obra, o autor faz literalmente apologia ao português como principal povo a compor a nação brasileira. Do ponto de vista dos nativos, ele os exclui totalmente, os considerando inaptos a fazer parte da nação. No "Discurso preliminar sobre os índios e a nacionalidade brasileira", diz o seguinte:

Em resumo: os Índios não eram donos do Brasil, nem lhe é aplicável como selvagem o nome de Brazileiros: não poderiam civilizar-se sem a presença da força, da qual não se abusou tanto como se assoalha; e finalmente de modo algum pode eles ser tomados para nossos guias no presente e no passado em sentimentos de patriotismo ou em representação da nacionalidade ${ }^{20}$.

A partir de Adolfo de Varnhagen, predominou na historiografia brasileira toda uma concepção (com exceção de Capistrano de Abreu) em que se coloca o índio apenas como figurante na construção da identidade nacional pensada naquele século. Nessas produções, se confirmam categoricamente toda uma tradição de conceitos pejorativos herdados dos três séculos de colonização. 
As afirmações de Varnhagem, se apoiam dentre outros elementos, na política de expropriação dos territórios dos nativos nos três séculos em que foram explorados e o forçoso encerramento nos aldeamentos. Naqueles redutos, os vários mecanismos que foram utilizados para cada vez mais minar sua resistência, foram, para a maioria deles, bastante nocivos aos seus referenciais culturais.

Há de se ressaltar que as tentativas de obliteração dos nativos passaram a se processar com maior sistematização a partir da instituição do Diretório Pombalino em 1758. Naquela oportunidade, o governo de Pombal instituiu várias medidas de reorganização da sociedade colonial, entre as quais a abolição da presença de religiosos nos aldeamentos e a instituição da língua portuguesa em detrimento da língua geral Tupi, foram algumas das principais ações.

Estudando as ações e consequências da Implementação do Diretório na Província do Ceará, Isabelle Braz Peixoto da Silva, em Vilas de índios no Ceará Grande: dinâmicas locais sob o Diretório Pombalino, destaca que era de suma importância considerar o "idioma como instrumento impositivo, na tentativa da substituição da cultura nativa pela cultura colonizadora." 21 As atuações do Diretório podem ser melhor compreendidas quando se observa o teor dos documentos que, a partir do Diretório, regulavam as Vilas de índios na Capitania de Pernambuco e sua anexas. Observemos

Sendo S.M.F. servido pelos alvarás com força de lei de 6 e 7 de junho de 1755 e 8 de julho de 1758 abolir a administração temporal, que os regulares exercitavão nas Aldêias d'este governo (...) determino, em execução dos referidos alvarás, e para que se verifiquem as suas reaes e pias intenções, que haja em cada uma das sobretidas Povoações, enquanto os índios não tiverem capacidade para se governar, um diretor que nomeará o govenador e o capitão geral d'estas capitanias dotado de bons costumes, zelo, prudência, siencia da língua e todas as mais circunsancia necessárias (...) serão um dos principais cuidados dos diretores estabelecer nas suas respectivas vilas ou logares o uso da língua portuguesa, não consentindo de modo algum, que os meninos e meninas, que pertencenrem a Escola e todos aquelles índios, que forem capazes de instrução nesta matéria, uzem da língua própria da suas nações ou da chamada língua geral, mas unicamente da portuguesa, na forma que sua Magestade tem recomendado e a repetidas ordens, que até agora se não observão com total ruina espiritual e temporal do estado ${ }^{22}$.

Essa política levou a historiadores como Varnhagen e outros estudiosos do século XIX e primeira metade do XX, a acreditarem no progressivo "desaparecimento" da população nativa. Varnhagen observa que:

se quereis saber que elementos de povoação predomina actualemnte no Brazil, percorrei as cidade e as villas. Vereis brancos de typo europeu, vereis alguns negros, vereis gente procedente destes dois sangues, e raramente, n'uma ou outra, encontreis rasgos physionomicos do typo índio, alias por si bem distincto. E isto não porque se exterminasse esta raça, porém sim porque eram os Índios em tão pequeno 
numero no paiz que foram absorvidos physicamente pelos outros dois elementos, como o foram moralmente ${ }^{23}$.

Por toda a primeira metade do século XIX, muitas medidas foram tomadas para cada vez mais minar as ações dos nativos. Tal situação se tornou clara após a chegada da família Real na Colônia, a qual instituiu Leis (em 1808 e 1809) que autorizavam a Guerra Justa e a escravização para os forçar a se incorporarem na sociedade dita civilizada ${ }^{24}$.

Outro momento importante em que se tentou decidir a situação dos nativos e que não modificou sua condição diante daquela realidade, foi quando se instituiu a Carta Constitucional de 1824. Nela, segundo Maria Hilda Paraiso, se discutiu e decidiu que os seus territórios ficariam melhor sob o domínio dos latifundiários, uma vez que estes eram os "únicos capazes de fazer produzir racionalmente as terras ocupadas pelos nativos". Ela observa que,

Constituía-se, portanto, um dever dos bem intencionados filantropos promover a nova ordem civilizada e iluminada e a ocupação/civilização da fronteira/selva, onde não se havia constituído a sociedade e as atividades econômicas calcavam-se no desperdício e na baixa produtividade porque as terras não eram exploradas de forma racional. Para que a civilização atingisse essas áreas inóspitas deveriam ser viabilizadas a ocupação e a colonização através das atividades agrícolas, da exploração da natureza e da apropriação da terra, sua repartição e acumulação por homens mais bem-dotados intelectualmente e previdentes que seus ocupantes indígenas $^{25}$.

Como se percebe, os debates giravam em torno da posse da terra. Nem mesmo a proposta de sua incorporação como cidadãos do Império contemplada no projeto de José Bonifácio de Andrada e Silva, conseguiu mover a bancada latifundiária a um posicionamente mais favorável ao índio. A ideia de Bonifácio de Andrada e Silva, era a

de criar aldeamentos como espaços de educação, ressocialização ("civilização") e catequese dos índios, facilitando, contudo, a miscigenação dos índios com "brancos" e "mulatos". A médio e longo prazo, o objetivo era a "nacionalização" e a "cidanização" dos índios, pois a meta, segundo ele, era "misturar as raças, ligar os interesses recíprocos dos índios com a nossa gente, e fazer deles todos um só corpo da nação, mais forte, instruída e empreendedora [...]",26

A resistência da elite agrária em não aceitar que os nativos tivessem a liberdade e o usufruto sobre suas terras, estava alicerçada nas Leis de 1808 e 1809. Em função delas, o índio só seria considerado cidadão caso aceitasse a cultura não-índia, ao contrário era considerado legítimo fazer guerras justas e tomarem seus territórios.

Nos passos desses instrumentos de coerção, sobretudo no modelo da produção nacional, os intelectuais do Instituto Histórico da Província do Ceará, trazem também relatos, 
discursos e imagens de um rápido processo de extinção dos índios naquele território. Perduram nessas obras os mesmos conceitos dos tempos dos primeiros contatos como os colonos - bárbaros, gentio, selvagens, incivilizados, justificando cada vez mais de que em um futuro próximo estariam dizimados ou fundidos na denominada categoria social cabocla ${ }^{27}$.

Tristão de Alencar Araripe, um importante estudioso da época, só para citar, assegurava que a "população indígena é insignificantíssima na província e tem quase totalmente desaparecido. Internando-se nos bosques uns, retirando-se do solo da província outros, mesclando-se os demais com as raças branca e preta, hoje os aborígenes já não se fazem notados pelo número (...),28

Esses desfechos em relação ao iminente fim das sociedades nativas, como já colocado, estava no bojo das inúmeras ideias que autoridades e os intelectuais defendiam e que expunham em livros, jornais e em outros meios de comunicação. Para o setor da administração da Província, mesmo quando se esboçou um levantamento da população no início do século XIX, não se tinha registrada a presença do povo nativo. Isto se observa num relatório apresentado pelo então Presidente José Martiniano de Alencar à Assembleia Legislativa, em 1836. No documento se observa o seguinte:

\begin{abstract}
Srs. he bem a meo pesar, que ainda nesta Sessão me veja obrigado a dizer-vos quase o mesmo, que na passada, isto he, que o arrolamento de 1813 he o único, que temos para conhecer-se a população de nossa Província. Exigi, e muito a tempo dos Parochos, e depois dos Juizes de Paz, pelo intermédio dos Juizes de Direito, os dados necessários para dar-vos hua Idea mais exacta da nossa população (...) Apenas chegarão ao tempo algumas relações remetidas pelos Juizes de Direito d'esta Comarca, e do Crato (...) desta mesma mandei organizar há relação, e dela vereis que estas duas Comarcas tem há população de 69:324 almas livres e 5:154 captivas $(\ldots)^{29}$
\end{abstract}

Não figurando nesses relatórios, bem como em outros documentos oficiais da administração, os nativos se tornariam uma categoria social a menos nas políticas de "proteção" às populações carentes da Província. A esses mecanismos de exclusão, veio a juntar-se também a ideia de que na conquista e colonização daquele território, os índios, ao travarem violentas guerras contra os "brancos" em sua defesa, foram praticamente todos extintos e os que sobreviveram foram reduzidos nos aldeamentos.

Para os sertões dos Cariris Novos, os discursos das autoridades locais e a produção historiográfica não fugiram a essas crenças. A compreensão era a de que os índios Kariri que ali habitaram estavam definhando a passos largos. Em $O$ Cariri, Irineu Pinheiro já assinalava que "desses nossos líticos antepassados, os Cariris, não restam hoje representantes"30, uma 
vez que "foi-lhes fatal, o trato com o homem civilizado, a quem tiveram de submeter-se a bem e a mal"31. Ali, os principais mecanismos de exclusão foram, sobretudo, através dos Aldeamentos $^{32}$ e do descimento ${ }^{33}$ para outras localidades da Província.

Diante desses episódios, estudiosos da história do Cariri, que tiveram suas produções publicadas a partir da segunda metade do século XX passaram a reproduzir com maior frequência a ideia desse desaparecimento. Para ilustrar ainda mais essa crença, num passado recente, no dia 19 de abril de 2008, o caderno regional do jornal Diário do Nordeste traz a seguinte reportagem:

Crato. Trezentos anos depois da chegada dos primeiros colonizadores no Sul do Estado, restam poucas informações sobre os índios Cariris, primeiros habitantes da região. A presença dos nativos foi parcialmente esquecida pelos historiadores oficiais. A memória dos Cariris foi apagada pelo tempo ${ }^{34}$.

Os argumentos mais recorrentes para essa ausência/esquecimento, além das "Guerras dos Bárbaros", foram a interação com outros índios, derivando grupos como: Xocó, Pankararu, Wakona-Kariri-Xukuru, Kariri-Xocó, Fulniô, Icó, Tuxá. Essa interação foi fruto de seu convívio nos aldeamentos.

Nos Cariris Novos, especialmente no Aldeamento Missão do Miranda, atual cidade do Crato, e Missão Velha, essa influência mútua somada aos rituais sacramentais do catolicismo, especialmente os do batismo e do catecismo dialogado ${ }^{35}$ auxiliaram na crença desse possível fim, notadamente o de sua língua. Ali, submetidos de maneira especial aos ditames dos frades capuchinhos Italianos, aos poucos a língua kariri foi sendo substituída pela língua geral tupi, como também se emaranhando com as dos demais nativos, de maneira que, com o passar do tempo, os Kariri não mais conseguiam se reconhecer nesse importante instrumento de comunicação.

Cristina Pompa destaca que "a língua é uma força ativa na sociedade, um meio pelo qual indivíduos e grupos controlam outros grupos ou resistem a esse controle, um meio para mudar a sociedade ou para impedir a mudança, para afirmar ou suprimir as identidades culturais. ${ }^{36}$ Dessa forma, deve-se compreender que essa interação, esses múltiplos relacionamentos tiveram sua "tradução" que marca, segundo Cristina Pompa a percepção e a devolução para outro da nova realidade." 37

Foi o que ocorreu durante o contato e a convivência dos Kariri com os ensinamentos dos preceitos do catolicismo nos aldeamentos. Naquele espaço os Kariri iam congregando muitos dos elementos da religião católica aos seus sistemas de crenças, levando, por sua vez aos seus comandantes a acreditarem na sua conversão e submissão na sociedade dita 
civilizada e não mais praticando suas crendices. Essas atitudes, invisíveis aos poderes eclesiásticos, induziam, especialmente a elite sacerdotal, à crença de que a doutrina cristã estava sendo amplamente absorvida e os tornando verdadeiros cristãos.

Naqueles sertões Sul, além das formas de submissões dos Kariri nos aldeamentos, a confiança no seu desaparecimento se tornou mais forte quando, os que ainda ali existiam, foram, em 1780, descidos para as aldeias situada no litoral da Província, especialmente para a da Parangaba, Baturité, Almofala e outros fugiram para as Matas da Serra do Araripe de onde não mais regressaram ${ }^{38}$. Vejamos o documento do referido descimento;

1780, 16 de outubro - Nesta data foram espoliados de suas terras e expulsos para Aronches, hoje Parangaba, os índios do Crato, por ordem do ouvidor José da Costa Dias e Barros. Prova-o o seguinte documento: Atestação. Atesto que fiz executar esta ordem quanto aos índios da vila do Crato em 16 do corrente, dia em que saíram da mesma vila para a de Aronches o que tudo presenciei, e quanto aos de Arneirós declarou o tenente-coronel Eufrásio Alves Feitosa, a quem incumbi a diligência, ser 20 do mesmo mês. O Escrivão da provedoria da fazenda registe esta para contar. Vila do Crato, 28 de outubro de $1780^{39}$.

Foi a partir desse descimento, que estudiosos locais e parte da sociedade não índia da região do Cariri projetou e acreditou no suposto "fim" dos Kariri. José de Figueiredo Filho, estudioso da História colonial daquela região, é enfático ao colocar que quando foram descidos para o aldeamento de Arronches (hoje Bairro da Parangaba - Fortaleza), "os indígenas cratenses se definharam, até o desaparecimento completo." 40

Por muito tempo, esse documento figurou como principal testemunha da hipotética ausência dos Kariri nos territórios Sul da Província. No entanto, integrantes dessa nação, nos finais do século XIX ainda permaneceram visivelmente atuante em lutas contra os usurpadores de suas terras. Há possibilidades destes nativos terem sido os descendentes dos que foram aldeados pelo capuchinho Frei Vital de Frescarolo na Aldeia Jacaré e Gameleira no início do século XIX, bem como os que foram descritos em 1838 pelo inglês George Gardner nas imediações da Vila de Jardim quando ali esteve realizando pesquisas, especialmente botânicas. Estes Kariri, por não terem mais seus territórios, sobreviviam de assaltos e ataques aos povoados e vilas daqueles sertões. Essas ações denunciam que naquele contexto os conflitos bélicos entre nativos e a sociedade dominadora ainda eram latentes.

João Leite destaca que "a continuidade das ações bélicas sugere uma política de agressões coerente com o processo de expropriação das terras indígenas, e, no Ceará, coerente com a construção do "desaparecimento" dos índios do território da capitania"41, onde suas terras eram praticamente ambicionadas para a criação de gado e o plantio do algodão que 
passa a prosperar a partir da segunda metade do século XIX com a instituição da Lei de Terras em 1850. Com a Lei, uma pequena elite agrária passou a concentrar consideráveis porções territoriais e intensificar cada vez mais o cultivo do algodão, cuja produção era quase toda direcionada para abastecer o mercado europeu, o qual estava carente do fornecimento das Colônias do Sul da América do Norte em função da Guerra de Secessão.

A instituição da Lei de Terras foi consequência das ações políticas do período regencial. Uma delas foi a revogação das Leis de 1808 e 1809 - abolindo a guerra justa e a extinguindo, definitivamente, os aldeamentos - cuja intenção era tornar os nativos livres, para serem potencialmente absorvidos como mão de obra, sobretudo, na agricultura. Todavia,

essas medidas ainda não satisfaziam plenamente os grandes proprietários rurais, novas facilidades de acesso às terras indígenas foram criadas através do Aviso de 31/07/1834, que transferiu a responsabilidade de fiscalização dos Juizes de Órfãos para as Câmaras Municipais, e da Lei de $\mathrm{N}^{\mathrm{o}} 16$ de 12/08/1834, que atribuía às Assembleias Legislativas Provinciais e Geral a responsabilidade de legislar sobre a catequese e civilização dos índios ${ }^{42}$.

De súditos e "protegidos" do rei, os nativos passavam agora para a tutela dos legisladores provinciais e dos grandes latifundiários, uma vez que, mais tarde, resultou na criação e implementação da mencionada Lei de Terras. Tal Lei foi

\begin{abstract}
Visível na implacável política de deslegitimação das comunidades étnicas, que impôs aos seus membros, às vezes de maneira violenta e outras de forma mais negociada, o estatuto jurídico e político de "brasileiros" e "cidadãos", o processo de "nacionalização" e "cidanização" da população indígena alcançou níveis decisivos a partir da segunda metade do século XIX. Neste período, iniciou-se a desamortização das terras dos índios, deslanchada em ritmo firme com a promulgação da Lei de Terras de 1850, dos seus regulamentos, em 1854, e de uma série de avisos e leis complementares, cujo objetivo precípuo era o de acabar com o domínio e uso comum sobre várias terras que eles possuíam na forma de sesmarias, missões, aldeamentos, compras e doações ${ }^{43}$.
\end{abstract}

Essas medidas tinham como pano de fundo razões ideológicas. Na época, estavam em efervescências as teorias evolucionistas e raciais. Através delas se buscava compreender, sobretudo, o grau de evolução das sociedades nativas em relação à civilização europeia. Manuela C. da Cunha destaca que "essa época, prosperou a ideia de que certas sociedades teriam ficado na estaca zero da evolução, e que eram portanto algo como fósseis vivos que testemunhavam do passado da sociedade ocidental." 44

Na província do Ceará, Celeste Cordeiro destaca que a segunda metade daquele século se caracterizou "um momento de grandes mudanças. Novas ideias ligadas ao cientificismo, ao liberalismo político abalaram as estruturas tradicionais do poder do velho patriarcalismo rural, abrindo caminho para república" ${ }^{45}$. Diante disto, se a Província do Ceará se arrogou ser a 
primeira a libertar os escravos, fruto do velho patriarcalismo, foi a primeira a "negar, insistentemente, a existência dos índios nas aldeias e a querer se apoderar de suas terras"46.

Essas mudanças também fizeram-se sentir nos Cariris Novos, especialmente nas suas mais expressivas Vilas, sobretudo a de Crato. Naquele núcleo urbano, tal contexto foi vivido com muita euforia. Foi o período em que se processava sua emancipação à cidade, que culminou em 17 de outubro de $1853^{47}$. Tal emancipação, atraiu um grande número de famílias para aquele ambiente, especialmente da cidade do Icó, que proporcionou maior importância aos projetos de civilidade ali planejados e executados. Na observação de José de Figueiredo Filho;

Naquela época, atingiria a dois mil ou mais o número de seus habitantes. Nos anos 50 do século XIX, prestes a ser cidade ou após sê-lo, organizou Crato vários serviços necessários à sua vida coletiva. Recordemos alguns que lhe foram realmente utilíssimos: a construção do mercado e do cemitério, uma elementar tentativa de abastecimento de água à cidade, a edição de seu primeiro Jornal, que indicou interessarem a elite muito reduzida, é certo, coisa da inteligência e do espírito ${ }^{48}$.

Construir um mercado, um cemitério e um elementar abastecimento de água foi uma das primeiras ações de preparar a cidade para entrar nos parâmetros da civilização. Sepultar seus entes queridos em local apropriado, racionalizar a atividade no mercado, eram passos decisivos a uma vila aspirante a cidade. A criação do jornal $O$ Araripe naquela vila, depois cidade, o primeiro no interior da Província, denunciava as pretensões da sociedade do Crato e demais localidades.

A prosperidade do setor urbano era, sobretudo, em função da agricultura e comércio. Local mais fértil da Província, as terras dos Cariris Novos que estavam em processo de valorização, iam tornando-se muitos mais custosas. Ali, naqueles terrenos havia a possiblidade de implementação da policultura, tendo a cana de açúcar como principal atividade lucrativa. Assim,

Ao lado das plantações de cana de açúcar e de outros gêneros agrícolas para consumo e mercado local, aventuraram-se alguns senhores em outros cultivos, como o café e o algodão. Os cafezais, contudo, tiveram pouca evidência para as lavouras dos senhores, posto que o café nunca chegou a determinar nem $10 \%$ da receita das cidades do Cariri, além de nos anúncios de vendas de propriedades ser anunciada como uma lavoura adjacente ${ }^{49}$.

A lavoura canavieira, pelo seu caráter expansionista e a produção de outros gêneros assim como a pecuária, passou a ocupar muito mais terras, e os Kariri, que ainda viviam sobre elas, foram cada vez mais sendo empurrados para as bordas daquela sociedade. Lá, nas fronteiras dos prósperos núcleos urbanos ficavam à espreita para atacar os usurpadores do seu 
principal meio de subsistência ou a mendigar a caridade dos citadinos abastados. Um importante exemplo desses assaltos são os dos já citados Xocó. Nos finais daquele século, perambulavam entre o Ceará e a Paraíba, atacando vilas vizinhas. Studart Filho elucida que “os Xocó e human (Umão), aliados aos Quipapá invadiram em 1843 o termo de Jardim, roubando e incendiando casas o que fizeram igualmente em Pernambuco e Paraíba. Em 1860, diz o autor, "existiam ainda no termo de Milagres uns trinta ou quarenta índios pertencentes à tribu dos Xocó." ${ }^{50}$ Sobre a mendicância dos Xocó, João Leite destaca que,

No ano de 1861, o governo do Ceará nomeou uma comissão chefiada por Pedro Theberge para averiguar a situação da população do termo de Milagres, localizada na parte sul da Provincia, na atual região do vale do Cariri. A comissão do Dr. Theberge deparou-se inesperadamente com um grupo selvagem de choco, que habitavam as fronteiras do Ceará com a Paraíba e Pernambuco. Da numerosa tribo restavam apenas 28 sobreviventes. Esses índios encontravam-se completamente expropriados de suas terras. Então, por questão de sobrevivência, foram forçados a construir suas moradas nas terras ocupadas por particulares ${ }^{51}$.

As informações acima colocadas, provocam relevantes discussões sobre a situação dos grupos de índios Kariri que rondavam vilas e cidades no Sul da Província do Ceará naquele século. É importante também para compreendermos que mesmo com todo o discurso de que eles não mais existiam, sua situação, embora de penúria ia os tornando visíveis aos olhos da população local.

A presença dos Xocó nos Cariris Novos nos finais do século XIX, demonstra a assertiva de que ainda haviam muitos deles dispersos pelo território provincial. Os estudos de João Leite asseguram os que foram efetuados por Maria Sylvia Porto Alegre nos anos oitenta/noventa do século XX. Lançando mão de uma variada tipologia de fontes, especialmente os Censos, Sylvia Porto Alegre, identificou que especialmente na segunda metade do século XIX, se processa a construção ideológica da categoria social "cabocla" pelos não-índios "identificada como o mestiço de origem indígena.",52

Por meio desses estudos é possível compreender a dimensão da dura realidade em que os nativos, especialmente os Kariri estavam enfrentando para reaver seus territórios, reorganizar seu mundo e melhorar a sua sobrevivência diante dentro de um contexto cuja complexidade era cada vez maior.

Com propostas bastante diferentes de manipular a natureza, de utilizar as forças produtivas, diversas formas de organizar seus meios de produção, os não índios fizeram produzir e reproduzir no meio da sociedade Kariri, novos espaços e novas experiências. Diante daquela realidade, estes nativos iam cada vez mais sofrendo as interferências daquela sociedade que se urbanizando carecia muito mais de terras para produzir sua materialidade. 
Com isto, os Kariri iam gradativamente sentindo rupturas mais acentuadas com seu passado/presente e experimentando cada vez mais dificuldades em resistir em seus habitats, em defender seus códigos culturais, enfim, seu sistema de valores e de crenças.

Essas mudanças foram cruciais para os nativos. Os laços que os uniam ao meio ambiente passaram a ficar mais distantes. A caça, as formas de manuseios dos recursos existentes nas matas, a pesca coletiva em rios e lagos, passam a ser atividades de um passado longínquo. Se realizavam algumas atividades, eram, agora, organizadas em terras alheias, cuja produção não mais as usufruíam por completo. Do ponto de vista de sua organização social, a quebra do aparelhamento político foi também outro momento de significativa mudança operada na cultura Kariri. Segundo Ferrari,

"as normas do comportamento tradicional, ora assimétricas - entre o capitão e os subordinados, entre pai e filhos -, ora simétricas - entre irmão entre caçadores - sofreram primeiro os efeitos desarticuladores da desorganização social, e depois a implantação de normas introduzidas pelos efeitos reintegradores da mudança." 53

O contato com novas técnicas de manusear e extrair da natureza recursos para sobrevivência (a caça, a pesca, a agricultura, a derrubada de matas, etc.), em função da exigência dos colonos, ocasionou para os Kariri o desafio de perceber que sua interferência no mundo natural e o infortúnio em desenvolver novas habilidades no uso de novos instrumentos (machados, foices, armas de fogo), já não era mais como antes e provocavam significativas mudanças na configuração da paisagem e no espaço em que atuavam. Em suas atividades produtivas, as ferramentas feitas de madeira ou pedra, utilizadas para tirar da natureza sua sobrevivência num sentido quase que ritual, eram a partir desse momento "substituídas" por outras sem nenhum significado cultural ${ }^{54}$.

O projeto colonizador, através de seus mecanismos de desarticulação, sobretudo tomada dos territórios e os aldeamentos, engendrou nos Kariri novos mecanismos de experiência espacial e temporal. Os nativos, "presos" nessas redes de poder, iam perdendo gradativamente o senso de organização coletiva, debilitando, assim, a eficácia das práticas culturais. Pajés e curandeiros não mais exerciam seus poderes miraculosos e não confortavam mais os espíritos inquietos de seus pares. Nem mesmo repassar seus saberes para os mais jovens era confiável, uma vez que estavam vendo seu mundo se desorganizar e as novas gerações sendo submetidas às orientações materiais e imateriais da sociedade dita civilizada.

De maneira inevitável, todo esse conjunto de elementos provocou problemas existenciais no mundo dos Kariri. Foi olhando para todos esses aspectos que a sociedade não- 
índia foi construindo toda uma concepção de que o fim da nação Kariri era questão de tempo. Localidade solidificada economicamente em função da produção da cana de açúcar, onde se forjou uma sociedade aristocrática, dominadora e excludente, a história dos Kariri passou a ser retratada apenas em suas lendas e nos parcos resquícios de sua cultura material.

No entanto, a nação Kariri assim como outras não foram passivas aos obstáculos impostos pela sociedade não-índia. Apesar das adversidades, jamais deixaram de resistir e existir. Presos nos aldeamentos, mantendo alianças com os não-índios ou errando pelas florestas, o sentimento de pertença a seus territórios e de querer retomá-los nunca cessou, isto porque, as complexas relações e experiências vividas com os adventícios lhe proporcionaram vários dispositivos de resistências, cujo elemento mais importante foi a luta pela preservação de sua memória. Porém, essa memória não operaria mais como antes. Como observou Eduardo Viveiro de Castro,

A memória e a tradição são o mármore identitários de que é feita a cultura. Estimamos, por fim, que uma vez convertidas em outras que si mesmas, as sociedades que perderam sua tradição não têm volta. Não há retroceder, a forma anterior foi ferida de morte; o máximo que se pode esperar é a emergência de um simulacro inautêntico de memória, onde a "etnicidade" e a má consciência partilham o espaço da cultura extinta ${ }^{55}$.

O turbilhão social no qual cada vez mais os Kariri eram envolvidos, os colocava diante de muitos desafios e os forçava "refundar" ou reorganizar sua realidade, a história de seu povo e a sua historicidade ${ }^{56}$. Foi se utilizando de vários mecanismos de resistência que estes nativos foram conseguindo enfrentar a força avassaladora de uma concepção de mundo totalmente alheia à sua, que os forçava a repensar e exercer cotidianamente novas posturas e formas de atuação para melhor sobreviver em novos cenários socais que se anunciava em cada contexto.

\section{Notas}

\footnotetext{
${ }^{1}$ No texto, o termo Cariri (C) remete a Região. Kariri (K) aos índios.

${ }^{2}$ PORTO ALEGRE, Maria Sylvia. Aldeias indígenas e povoamento do Nordeste no final do século XVIII: Aspectos demográficos da "cultura de contato". In: XVI Encontro Anual da ANPOCS. Caxambu: MG. 20 a 23 de outubro de 1992. p.1-18. (GT História Indígena e do Indigenismo)

3 ___ Cultura e história: sobre o desaparecimento dos povos indígenas. In: Revista de Ciências Sociais. Fortaleza: vol., 23/24, n.1/2,1992/1993, p. 213-225

${ }^{4}$ MONTEIRO, John Manuel. Negros da Terra: índios e Bandeirantes nas origens de São Paulo. São Paulo: Companhia das Letras, 1994

${ }^{5}$ CUNHA, Manuela Carneiro da. História dos Índios no Brasil (org.); São Paulo: Companhia das Letras, 1992

${ }^{6}$ PUNTONI, Pedro. A guerra dos Bárbaros: povos indígenas e a colonização do sertão nordeste do Brasil. 1650-1720. São Paulo: HUCITEC, 2002.
} 
${ }^{7}$ REIS, José Carlos. As Identidades do Brasil: de Varnhagen a FHC. 6 a edição. Rio de Janeiro: FGV, 2003, p. 24 ${ }^{8}$ NASCENTE, Livia Silva da. Política e Construção da identidade Nacional: os Índios na História do Brasil. In: Revista Litteris - Ciências Humanas - Antropologia. Niterói: n.6., novembro, 2010, p. 1-15

${ }^{9}$ PATACA, Ermelinda Moutinho; PINHEIRO, Rachel. Instruções de viagem para a investigação científica do território brasileiro. In: REVISTA DA SBHC, Rio de Janeiro: vol., 3, n.1, janljun, 2005, p. 58-79

${ }^{10}$ Ibidem., p.58-79

${ }^{11}$ FARIAS FILHO, Waldemar Arraes de. Crato: Evolução Urbana e Arquitetura 1740-1960. Fortaleza: Expressões Gráfica e Editora, 2007, p.98

${ }^{12}$ DAMACENO, Narcy; CUNHA, Waldir da. Os Manuscritos do Botânico Freire Alemão: In: Anais da Biblioteca Nacional do Rio de Janeiro: Vol. 81, 1964, p. 280

${ }^{13}$ NASCIMENTO, Narcy. op. cit., p. 285

${ }^{14} \mathrm{O}$ termo nação é recorrente na documentação não só do século XIX, mas também nos séculos anteriores. Foi cunhado pelos colonizadores para definir os índios que tinham práticas culturais comuns.

${ }^{15} \mathrm{O}$ termo etnia será utilizado para identificar grupos participantes de uma mesma nação. Como exemplo; KaririXocó; Xucuru-Kariri.

${ }^{16}$ DAMACENO, Narcy; CUNHA, Waldir da. op. cit., p.314

${ }^{17}$ PRIMÉRIO, Pe. Frei Fidelis M. de. Capuchinhos Em Terras de Santa Cruz nos séculos XVII, XVIII e XIX. São Paulo: Livraria Martins, 1942, p. 171-174. (Biblioteca da Província Nossa Senhora da Penha do Nordeste do Brasil dos Frades Capuchinhos Italianos-Recife)

${ }^{18}$ DAMACENO, Narcy; CUNHA, Waldir da. op. cit., p. 334

${ }^{19}$ FETZ, Marcelo. Expedições cientificas no século XIX: O universo da Ciência e a diversidade cultural. In: Cadernos de Campo. São Paulo: USP, p. 39-54

${ }^{20}$ ADOLFO, Francisco Varnhagen de. Discurso preliminar: Os índios ante a nacionalidade, In: História Geral do Brazil. Rio de Janeiro: Madri-Imprensa J. del Rio, 1887, p. 15-28

${ }^{21}$ SILVA, Isabelle Braz Peixoto. Vilas de índio no Ceará Grande: dinâmicas locais sob o Diretório Pombalino. Campinas: Universidade Estadual de Capinas. Instituto de Filosofia e Ciências Humanas, 2003, p.86 (Tese de doutorado)

${ }^{22}$ Direção com que interinamente se deve regular os índios das novas Vilas e lugares erectos nas aldeias da capitania de Pernambuco e suas anexas. In: Revista do Instituto Histórico e Geográfico Brasileiro. Rio de Janeiro: Tomo XLVI, 1883, p. 121-171

${ }^{23}$ ADOLFO, Francisco Warnhagen de., op. cit., p. 15-28

${ }^{24}$ NETO, João Leite. Índios e Terra-Ceará. 1850-1880. Recife: Universidade Federal de Pernambuco. Departamento de História. 2006, p.113. (Tese de doutorado)

${ }^{25}$ PARAISO, Maria Hilda Baqueiro. Construindo o Estado de Exclusão: os Índios brasileiros e a constituição de 1824. In: CLIO: Revista de Pesquisa Histórica. n. 28.2, 2010, p. 1-17

${ }^{26}$ MOREIRA, Vânia Maria Losada. Notas sobre a "cidanização" e desamortização das terras de índios no Império brasileiro. In: XXVII Simpósio Nacional de História. Conhecimento Histórico e diálogo Social, ANPHU. Rio Grande Norte. 22 a 26 de julho de 2013. p. 1-15

${ }^{27}$ Para uma melhor compreensão sobre a construção dessa categoria social no século XIX, Cf.: OLIVEIRA, Maico Xavier. Cabôcullos são os Brancos": Dinâmica das relações socioculturais dos índios do Termo da Vila Viçosa Real (século XIX). Fortaleza: SECULT\CE, 2012

${ }^{28}$ ARARIPE, Tristão Alencar de. História da Província do Ceará: desde os tempos primitivos até 1850. [1858] 2002. Fortaleza: Fundação Demócrito Rocha, p. 61

${ }^{29}$ Informações apresentada pelo então Presidente José Martiniano de Alencar, na Sessão realizada em primeiro de agosto de 1836. p. 3 e 4. Arquivo Público do Estado do Ceará

${ }^{30}$ PINHEIRO, Irineu. O Cariri. (Edição Fac-símile a de 1950) Coleção SeculttEdições URCA.-Fortaleza: Edições UFC, 2010, p. 10

${ }^{31}$ Ibidem., p. 10

${ }^{32}$ Os aldeamentos na sua definição mais genérica se configuravam em redutos construídos pelos religiosos para reunir índios oriundos de diversos locais da colônia, cujos principais motivos eram, especialmente, por aprisionamentos mediante as chamadas guerras justas.

${ }^{33}$ Grosso modo, se configurava nas expedições de caça aos nativos que se internavam nos longínquos sertões afim de não colaborarem com os colonos na empresa colonizadora. Quando presos, eram descidos (levados) para os aldeamentos próximo ao litoral.

${ }^{34}$ Disponível em www.diariodonordeste.verdesmares.com.br.Acessado em 20/09/2010

${ }^{35} \mathrm{O}$ catecismo dialogado foi uma pratica muito comum utilizada pelos religiosos para doutrinar os nativos, aonde a pergunta não era propriamente o mais importante, mas as respostas dos catecúmenos.

${ }^{36}$ BURKE, Peter. A arte da conversação. São Paulo: Unesp, 1995, p.41 


\footnotetext{
${ }^{37}$ POMPA, Cristina. Religião como tradução: missionários, Tupi e Tapuia no Brasil Colonial. São Paulo: EDUSC, 2003, p.350.

${ }^{38}$ PRIMERIO, Padre Frei Fidelis M. de. op. cit., p.1942, p.175

${ }^{39}$ PINHEIRO, Irineu. op. cit., p.48

${ }^{40}$ FIGUEIREDO FILHO, José de. História do Cariri. vol., I. (edição fac-símile à de 1964). Edições SecultIURCA.-Fortaleza: Edições UFC, 2010. p.39

${ }^{41}$ NETO, João Leite. op. cit., p.114.

${ }^{42}$ PARAISO, Hilda. op. cit., p. 1-17

${ }^{43}$ MOREIRA, Vânia Maria Losada. op. cit., p.1-15

${ }^{44}$ CUNHA, Manuela Carneiro da. Introdução a uma história indígena. In: CUNHA, Manuela Carneiro da. (org.); História dos Índios no Brasil São Paulo: Companhia das Letras, 1992. p.10

${ }^{45}$ CORDEIRO, Celeste. O Ceará na segunda metade do século XIX. In: Uma Nova História do Ceará (org.);SOUZA, Simone de. Fortaleza: Edições Demócrito Rocha, 2003, p. 135

${ }^{46}$ NETO, João Leite. op. cit., p.113.

${ }^{47}$ FIGUEIREDO FILHO, José de. Cidade do Crato. (Edição Fac-símile a de 1955) Coleção SeculttEdições URCA.- Fortaleza: Edições UFC, 2010

${ }^{48}$ Ibidem., p.11

${ }^{49}$ CORTEZ, Ana Isabel Ribeiro Parente; CORTEZ, Ana Sara Ribeiro Parente; IRFFI, Guilherme. Atividades Econômicas e Trabalho Escravo no Sul do Ceará: uma análise da segunda metade do século XIX. In: IPECE. 2011. Disponível em: ww.ipece.ce.gov.br/economia-do-ceara-em-debate/vii-encontro/artigos. Acessado em 25 de fevereiro de 2016

${ }^{50}$ STUDAR TFILHO, Carlos. Nota Histórica Sobre os Indígenas Cearenses. In: Revista do Instituto do Ceará. Tomo XLV, Fortaleza: 1931, p.53-103

${ }^{51}$ NETO, João Leite. op. cit., p.130

${ }^{52}$ PORTO ALEGRE, Maria Sylvia. Id.1992/1993, p. 213-225

${ }^{53}$ FERRARI, Afonso Trujillo. Os kariri o crepúsculo de um povo sem história. São Paulo: 1957, p. 65

${ }^{54}$ SIQUEIRA, Baptista. Os Cariris do Nordeste. Rio de Janeiro: Editora Cátedras, 1978

${ }^{55}$ CASTRO, Eduardo Viveiros de. A inconstância da Alma Selvagem e outros ensaios de Antropologia. São Paulo: Cosac \& Naify, 2002.p.195

${ }^{56}$ POMPA, Cristina. Cartas do Sertão: a catequese entre os Kariri no século XVII. In: Revista Antropológica, ano 7, Vol., 14. (1e 2): 2003, p.7-33
}

\section{Referências Bibliográficas}

ADOLFO, Francisco Varnhagen de. História Geral do Brasil. Rio de Janeiro: 1887

ARARIPE, Tristão Alencar de. História da Província do Ceará: desde os tempos primitivos até 1850. [1858] 2002. Fortaleza: Fundação Demócrito Rocha.

BURKE, Peter. A arte da conversação. São Paulo: Unesp, 1995.

CASTRO, Eduardo Viveiros de. A inconstância da Alma Selvagem e outros ensaios de Antropologia. São Paulo: Cosac \& Naify. 2002.

CUNHA, Manuela Carneiro da. (org.); História dos Índios no Brasil. $2^{a}$ edição. São Paulo: Companhia das Letras, 1992.

SOUZA, Simone de. Uma Nova História do Ceará (org.); Fortaleza: Edições Demócrito Rocha, 2003.

CORDEIRO, Celeste. “O Ceará na segunda metade do século XIX”. In: Uma Nova História do Ceará. (org.); In: SOUZA, Simone de. Fortaleza: Edições Demócrito Rocha, 2003

CORTEZ, Ana Isabel Ribeiro Parente; CORTEZ, Ana Sara Ribeiro Parente; IRFFI, Guilherme. Atividades Econômicas e Trabalho Escravo no Sul do Ceará: uma análise da segunda metade do século XIX. IPECE. 2011. Disponível em: ww.ipece.ce.gov.br/economiado-ceara-em-debate/vii-encontro/artigos. Acessa em 25 de fevereiro de 2016

FARIAS FILHO, Waldemar Arraes de. Crato: Evolução Urbana e Arquitetura 1740-1960. Fortaleza: Expressões Gráfica e Editora, 2007 
FIGUEIREDO FILHO, José de. Cidade do Crato. (edição Fac-símile a de 1955) Coleção SeculttEdições URCA.- Fortaleza: Edições UFC, 2010

. História do Cariri. vol., I. (edição fac-símile à de 1964)

Edições Secult|URCA.-Fortaleza: Edições UFC, 2010

FERRARI, Afonso Trujillo. Os kariri o crepúsculo de um povo sem história. São Paulo: 1957 MONTEIRO, John Manuel. Negros da Terra: índios e Bandeirantes nas origens de São Paulo. São Paulo: Companhia das Letras, 1994

MOREIRA, Vânia Maria Losada. Notas sobre a "cidadanização" e desamortização das terras de índios no Império brasileiro. In: XXVII Simpósio Nacional de História. Conhecimento Histórico e diálogo com Social.-ANPHU. RN. 22-26 de julho de 2013.

NASCENTE, Livia Silva da. Política e Construção da identidade Nacional: os Índios na História do Brasil. In: Revista Litteris - Ciências Humanas - Antropologia. Niterói: n.6., novembro, 2010

NETO, João Leite. Índios e Terra-Ceará. 1850-1880. Recife: Universidade Federal de Pernambuco. Departamento de História. 2006. (Tese de doutorado)

PARAISO, Hilda. Construindo o Estado de Exclusão: os Índios brasileiros e a constituição de 1824. In: CLIO: Revista de Pesquisa Histórica. Recife: Vol. 28.2. 2010

PATACA, Ermelinda Moutinho; PINHEIRO, Rachel. Instruções de viagem para a investigação científica do território brasileiro. In: REVISTA DA SBHC, Rio de Janeiro: vol., 3, n.1, janljun, 2005

PINHEIRO, Irineu. Efemérides do Cariri. (edição Fac-símile a de 1963)Coleção Secult|Edições URCA.-Fortaleza: 2010

O Cariri. (edição Fac-símile a de 1950) Coleção Secult. EdiçõeslURCA.-

Fortaleza: Edições UFC, 2010

UFC, 2010

PRIMERIO, Padre Frei Fidelis M. de. Capuchinhos Em Terras de Santa Cruz nos séculos XVII, XVIII e XIX. São Paulo: Livraria Martins, 1942

POMPA, Cristina. Cartas do Sertão: a catequese entre os Kariri no século XVII. In: Revista Antropológica, ano 7, Vol. 14. (1e 2), 2003

Paulo: EDUSC, 2003

Religião como tradução: missionários, Tupi e Tapuia no Brasil Colonial. São

PORTO ALEGRE, Maria Sylvia. Cultura e história: sobre o desaparecimento dos povos indígenas. In: Revista de Ciências Sociais. Fortaleza: vol., 23/24, n.1/2,1992/1993

Aldeias indígenas e povoamento do Nordeste no final do século

XVIII: Aspectos demográficos da "cultura de contato". In: XVI Encontro Anual da ANPOCS.

Caxambu: MG. 20 a 23 de outubro de 1992. p.1-18. (GT História Indígena e do Indigenismo)

PUNTONI, Pedro. A guerra dos Bárbaros: povos indígenas e a colonização do sertão nordeste do Brasil. 1650-1720. São Paulo: HUCITEC, 2002

STUDARTFILHO, Carlo. Nota Histórica Sobre os Indígenas Cearenses. In: Revista do Instituto do Ceará. Tomo XLV. 1931

SILVA, Isabelle Braz Peixoto. Vilas de índio no Ceará Grande: dinâmicas locais sob o Diretório Pombalino. Campinas: Universidade Estadual de Capinas. Instituto de Filosofia e Ciências Humanas, 2003, p.86 (Tese de doutorado)

SIQUEIRA, Baptista. Os Cariris do Nordeste. Rio de Janeiro: Editora Cátedras. 1978

CASTRO, Viveiros de. A inconstância da Alma Selvagem e outros ensaios de Antropologia.

São Paulo: Cosac \& Naify. 2002.

REIS, José Carlos. As Identidades do Brasil: de Varnhagen a FHC. $6^{\text {a }}$ edição. Rio de Janeiro: FGV, 2003 


\section{Documentos}

Informações apresentada pelo então Presidente José Martiniano de Alencar, na Sessão realizada em primeiro de Agosto de 1836. p. 3 e 4. APEC. (Arquivo Público do Estado do Ceará)

Direção com que interinamente se deve regular os índios das novas Vilas e lugares erectos nas aldeias da capitania de Pernambuco e suas anexas. Tomo XLVI, 1883, p. 121-124. Revista do Instituto Histórico e Geográfico Brasileiro.

Caderno regional de 19/04/2008. Diário do Nordeste. Disponível em www.diariodonordeste.verdesmares.com.br.Acessado em 20/09/2010

Os Manuscritos do Botânico Freire Alemão. Vol. 81. 1964. p. 280. Anais da Biblioteca Nacional do Rio de Janeiro. 